\title{
CURRENT TRENDS IN THE DEVELOPMENT OF THE WATER MANAGEMENT COMPLEX: UKRAINIAN REALITIES AND INTERNATIONAL EXPERIENCE
}

\author{
Lyudmila Levkovska', Inna Irtyshcheva², Iryna Dubynska ${ }^{3}$
}

\begin{abstract}
Aim. The ratification of the Paris Agreement by Ukraine envisages an increase in the ability to adapt to the negative effects of climate change, as well as promoting low carbon development so as not to endanger food production. At the same time, water resources, on the one hand, are one of the most vulnerable to climate change components of the environment from the state of which the food security of the country depends directly, and on the other hand, the activity of the water management complex causes the emergence of both direct and indirect carbon footprint. Therefore, an indispensable prerequisite for sustainable low carbon development is the assessment of the carbon footprint of the main sectors of Ukraine's water management complex and the identification of priority measures for their decarbonisation and adaptation to expected climate change. Methods. The methodological basis for the assessment of the carbon footprint of the main sectors of the water management complex was the life cycle method (LCA), by which, based on the open data of the National Inventory of Anthropogenic Emissions from Sources and Absorption by Greenhouse Gas Absorbers in Ukraine and the statistical analysis of the results of previous studies. By means of systematic analysis of the main factors of greenhouse gas emission in the water management complex of Ukraine, the priority directions of its decarbonisation and adaptation to climate change were determined. Results. The estimated carbon footprint of Ukraine's water complex in 2017 was estimated to be 5.15 million tons of $\mathrm{CO}_{2}$-equiv, which was $1.6 \%$ of the total greenhouse gas emissions in Ukraine in 2017, and taking into account the potential carbon footprint enduse processes can be increased by up to $3 \%$. Due to the deterioration of the water supply networks, an average of $35 \%$ of the supplied water is lost in Ukraine. Reducing network leakage by at least $10 \%$ will reduce carbon footprint by 30,000 tons of $\mathrm{CO}_{2}$-equiv annually. The priority areas for decarbonisation of the water management complex should be modernization of water supply and water treatment infrastructure, improvement of energy efficiency of pumping equipment and introduction of drip irrigation, and its adaptation to climate change development of the network of green infrastructure. Conclusions. The low-carbon development of the water management system should include the introduction and coordination of such measures, which, on the one hand, minimize the adverse effects of climate change on water resources and contribute to reducing the carbon footprint of water management activities, and on the other hand, guarantee the achievement of sustainable development goals, in particular for ensuring water and society proper sanitary conditions.
\end{abstract}

Key words: carbon footprint, water management complex, adaptation, decarbonisation, climate change.

JEL Classification: F01, R14, Q28, Q29

\section{Introduction}

One of the current global challenges for humanity is climate change and related transformations of hydrometeorological and hydrological conditions. In the context of the formation of new socio-economic relations, this requires a quality solution to the problem of sustainable water supply, because in the $21^{\text {st }}$ century, access to quality water resources for most consumers

Corresponding author:

${ }^{1}$ Public Institution «Institute of Environmental Economics and Sustainable Development

of the National Academy of Sciences of Ukraine», Ukraine.

E-mail: levlv@ukr.net

ORCID: https://orcid.org/0000-0002-7823-7062

${ }^{2}$ Admiral Makarov National University of Shipbuilding, Ukraine.

E-mail: innauamd@gmail.com

ORCID: https://orcid.org/0000-0002-7025-9857

${ }^{3}$ Admiral Makarov National University of Shipbuilding, Ukraine.

E-mail: management@nuos.edu.ua

ORCID: https://orcid.org/0000-0003-0709-0187 
will be much more difficult due to population growth and rapid urbanization. The concept of low-carbon development is a relatively new model of the political, economic and social structure of society, aimed at reducing greenhouse gas emissions and achieving sustainable development goals. The primary task of implementing this concept is decarbonising all areas of the economy, increasing energy efficiency and ensuring global ecological balance (Hu, Peng and Dequn, 2011).

Among the studies of recent years to assess changes in water regime in the basins of the main rivers of Ukraine should be noted the Ukrainian Hydrometeorological Institute of the National Academy of Sciences of Ukraine (2020). On the basis of the analysis of long-term dynamics of average annual water runoff the study contains the forecast modelling based on regional climate models on the basis of scenarios of climate change in Ukraine until 2050 and contains the basics of a comprehensive approach to assessing current and possible changes in river runoff.

The applied models show that a slight increase in the average annual water runoff can be expected on the mountain rivers of Crimea and in the Kalmius river basin - up to $2-4 \%$. Water flow up to $10 \%$ is possible on the rivers of Polissia. The water content of the Carpathian rivers and the northern part will not change. On other rivers there will be a decrease in runoff. Its largest decrease (up to 12\%) is possible on the rivers of the Black Sea coast. Probable changes are also in the intra-annual distribution of river runoff: an increase in the runoff of the winter low and a shift in the onset of spring floods to earlier dates.

At the same time, research (Haidutskyi, 2014) shows that there is no universal way to transition sectoral economic systems to sustainable low-carbon development. This transition is determined by the unique characteristics of each area of economic activity of society and requires the implementation of specific mutually agreed adaptation and decarbonisation measures, which would be based on an appropriate assessment of total greenhouse gas emissions from economic activities (carbon footprint) and the main factors of its occurrence. Therefore, the purpose of the study is assessing current trends in the development of the water complex of Ukraine through the prism of international experience.

\section{Analysis of the development of the water management complex of Ukraine using international experience}

Analysis of the carbon footprint of the main sectors of the water management complex of Ukraine can be performed using the life cycle assessment method (LCA) accredited according to international standards ISO 14044 (International Standard Organisation,
2006), which allows identifying the total carbon footprint of a particular production process, final product or service, taking into account all stages of their formation. Life cycle assessment (LCA) is carried out in four main stages, namely:

1. Defining the purpose and scope of the study.

2. Analysis of the life cycle inventory of the final product (LCI).

3. Assessment of the impact of final production on the environment (LCIA).

4. Interpretation of the obtained results and substantiation of further directions of research.

The first stage is the collection of general information about the study object, comparison and evaluation of the main input and output streams of its impact on the environment throughout the life cycle of the final product. In the context of this study, only output stream of impact was considered, namely the direct and indirect carbon footprint of water management activities at the stages of water intake, water supply, drainage and water treatment in municipal, industrial and reclamation complexes (Figure 1).

Inventory analysis, which provides for the collection of information and quantification of inputs and outputs of final products at all stages of the life cycle was conducted based on data from the Ukraine's Greenhouse Gas Inventory in 2017 and by determining energy consumption water management in major sectors of Ukraine.

The third stage of the method (LCA) aims to determine the magnitude and significance of the impact of the production process on the environment. In this context, a comparative evaluation of the results was obtained on the carbon footprint of water management in Ukraine and other countries, and also on the basis of the system analysis of the basic factors in a water management complex of Ukraine the priority directions of its decarbonisation are defined. Interpretation of the results obtained after the inventory analysis and assessment of the carbon footprint impact on the environment in accordance with the fourth stage (LCA) allowed to suggest ways and directions of adaptation of the water management complex of Ukraine to the expected climate change in order to minimize their possible negative consequences. Among all management models in the system of municipal services of different countries it is expedient to allocate three most successful and developed types: English model, which provides for full privatization of housing and communal services; German, created on the basis of the corporatization of enterprises with a majority stake in the municipality, and French, which combines municipal ownership of housing and communal services and management from private businesses on the terms of long-term leases and aggregate investment agreements. 


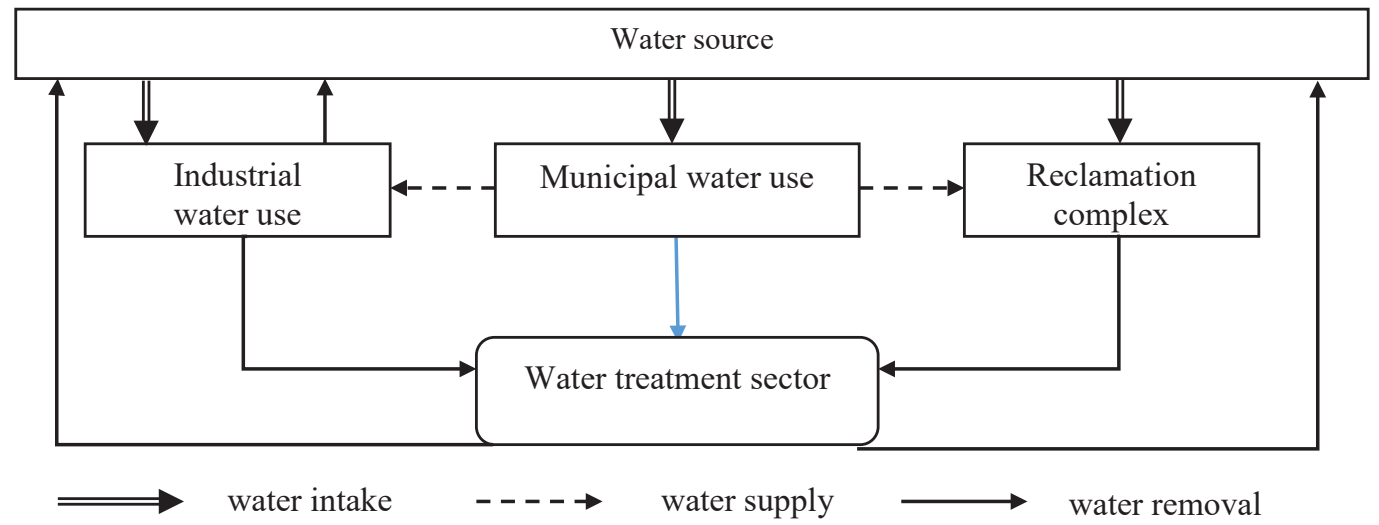

Figure 1. Main components of water life cycle assessment in water management complex of Ukraine

\section{Economic diagnostics of efficiency of development of water management complex of Ukraine and international experience of its spatial organization}

The largest issuer of direct greenhouse gas emissions in the water management complex of Ukraine is the wastewater treatment and discharge sector. The volume and structure of emissions in this sector are presented in Ukraine's Greenhouse Gas Inventory.

The calculations used data (Fritsche, 1997), which were obtained as a result of 10-year studies performed using the Global Emission Model for Integrated Systems and coincide with the results of other studies (Table 1).

Thus, the weighted average value of greenhouse gas emissions from electricity production in Ukraine in 2017 was 146.14 grams of $\mathrm{CO}_{2}$-equiv/kWh. Thus, the carbon footprint of the main sectors of the water management complex of Ukraine in 2017, according to our calculations, was equal to 5.15 million tons of $\mathrm{CO}_{2}$, which is $1.6 \%$ of the total greenhouse gas emissions in Ukraine in 2017. This figure is slightly lower than similar, which was calculated, for example, for the United States. In particular (GriffithsSattenspiel and Wendy, 2009), the total carbon footprint associated with the transportation, use, treatment, and heating of water in major sectors of the U.S. water management complex was 290 million tons of $\mathrm{CO}_{2}$ that was $5 \%$ of total U.S. greenhouse gas emissions in 2007.

In the context of this, we can identify two main areas of low-carbon development of water management complex of Ukraine. The first concerns the immediate reduction of direct greenhouse gas emissions, in particular in the field of water treatment. The second involves the implementation of measures aimed at minimizing the indirect carbon footprint of water management activities by increasing the overall energy efficiency of the relevant infrastructure.

In addition, in order to achieve the goals of sustainable development of water management, it is necessary to carry out adaptation measures for global climate change in the field of water supply, which can be aimed at regulating the demand for water resources or their offers. The former contributes to improving the efficiency using water, usually through the widespread use of economic instruments and the introduction of new technologies. These include: accounting, limiting and standardizing water use, setting water prices, developing water markets and trading in virtual water, implementing re-sequential water use systems, and more. Measures aimed at regulating the supply of water resources include, first of all, increasing the useful volume of reservoirs, water abstraction from surface watercourses and underground sources, water transportation, etc. (Figure 2).

Table 1

Determination of the weighted average value of greenhouse gas emissions in the process of electricity production in Ukraine in $2017, \mathrm{CO}_{2}$-equiv/ $\mathrm{kWh}$

\begin{tabular}{|c|c|c|c|c|c|c|c|}
\hline \multirow{2}{*}{$\begin{array}{l}\text { Electricity } \\
\text { generation } \\
\text { method }\end{array}$} & \multicolumn{2}{|c|}{ Electricity generation } & \multicolumn{2}{|c|}{$\begin{array}{l}\text { Greenhouse gas emissions } \\
\left(\mathrm{CO}_{2} \text {--equiv } / \mathrm{kWh}\right)\end{array}$} & \multirow{2}{*}{$\begin{array}{l}\text { Total GGE, } \\
\text { million tons }\end{array}$} & \multicolumn{2}{|c|}{$\begin{array}{l}\text { The weighted average value of } \\
\text { GGE in the production of } 1 \mathrm{kWh}\end{array}$} \\
\hline & structure, $\%$ & $\begin{array}{l}\text { amount, } \\
\text { billion } \mathrm{kWh}\end{array}$ & gram & tone & & gram & tone \\
\hline NPP & 55.1 & 85.63 & 35 & 0.000035 & 3 & 146.14 & 0.000146 \\
\hline HPP (coal) & 36.9 & 57.34 & 1000 & 0.001 & 57.34 & & \\
\hline GPS & 6.8 & 10.57 & 33 & 0.000033 & 0.35 & & \\
\hline WF/SPP/BPP & 1.2 & 1.86 & 50 & 0.00005 & 0.093 & & \\
\hline Total & 100 & 155.4 & & & 60.783 & & \\
\hline
\end{tabular}


As the main part of the carbon footprint in the water management complex of Ukraine (4.040 million tons of $\mathrm{CO}_{2}$-equiv) is generated in the field of wastewater treatment, the priority measures for decarbonisation of the water management complex should be aimed at modernizing the relevant water treatment infrastructure. Such measures include:

- introduction of new production technologies to reduce water consumption and wastewater generation;

- stimulating the development and use of new water treatment methods;

- introduction of an integrated wastewater management system to ensure their reuse.

Given the above, the priority measures to reduce the level of the indirect carbon footprint of the water management complex of Ukraine should be the replacement of worn-out water supply networks and modernization of pumping equipment in the sector of housing and communal water supply. In the reclamation complex, an effective method for reducing the indirect carbon footprint is the introduction of drip irrigation systems, which reduce the using water by $50-500 \%$, electricity (50-70\%), fertilizers (20-50\%). Irrigation efficiency reaches $85-90 \%$, as water enters directly into the root system of plants, the surface area of which is from 40 to $60 \%$ of the total area (Griffiths-Sattenspiel and Wendy, 2009). Also, evaporation losses are reduced and there are no losses from peripheral water runoff. A promising area for decarbonisation of reclamation and industrial complexes is the implementation of wastewater (gray) for irrigation in special areas - agricultural irrigation fields and production needs in reusable water supply systems.

The experience of the city of Königsbrück (Germany) in the implementation of public- private partnership in the treatment plant project is interesting (Figure 3), as it did not relieve the local government of responsibility for fulfilling its high duty - sewage disposal. They delegated its removal to a private individual, but not the task. Legal relations exist between local governments and the citizen (fees and contributions), on the one hand, and local governments and those who operate buildings and receive remuneration for their work from municipal authorities on the basis of private law - on the other hand.

According to current German law, operating models must be put up for competition. The Independent Consulting Bureau for Engineering and Economic Affairs has been instructed to develop a draft permitting procedure for the Königsbrück Wastewater Treatment Plant Competition. Upon the completion, this project sent for approval and verification to the water supervisory authorities. In parallel with the development of the draft permitting procedure, an examination of the construction soil at the site of the future treatment plant and a geodetic survey were carried out.

Thus, the use of wastewater in particular in agriculture is one of the integrated use measures and water resources protection, because the soil is able to treat wastewater, increasing its own fertility. At irrigation by sewage three tasks are solved: removal and clearing of the polluted waters; their use in the fields for artificial soil moisture; application of a large amount of mineral, organic and bacterial fertilizers to the soil. Taken together, this can significantly reduce the carbon footprint level in water management.

A significant climate change level impact on the state of water resources necessitates the development

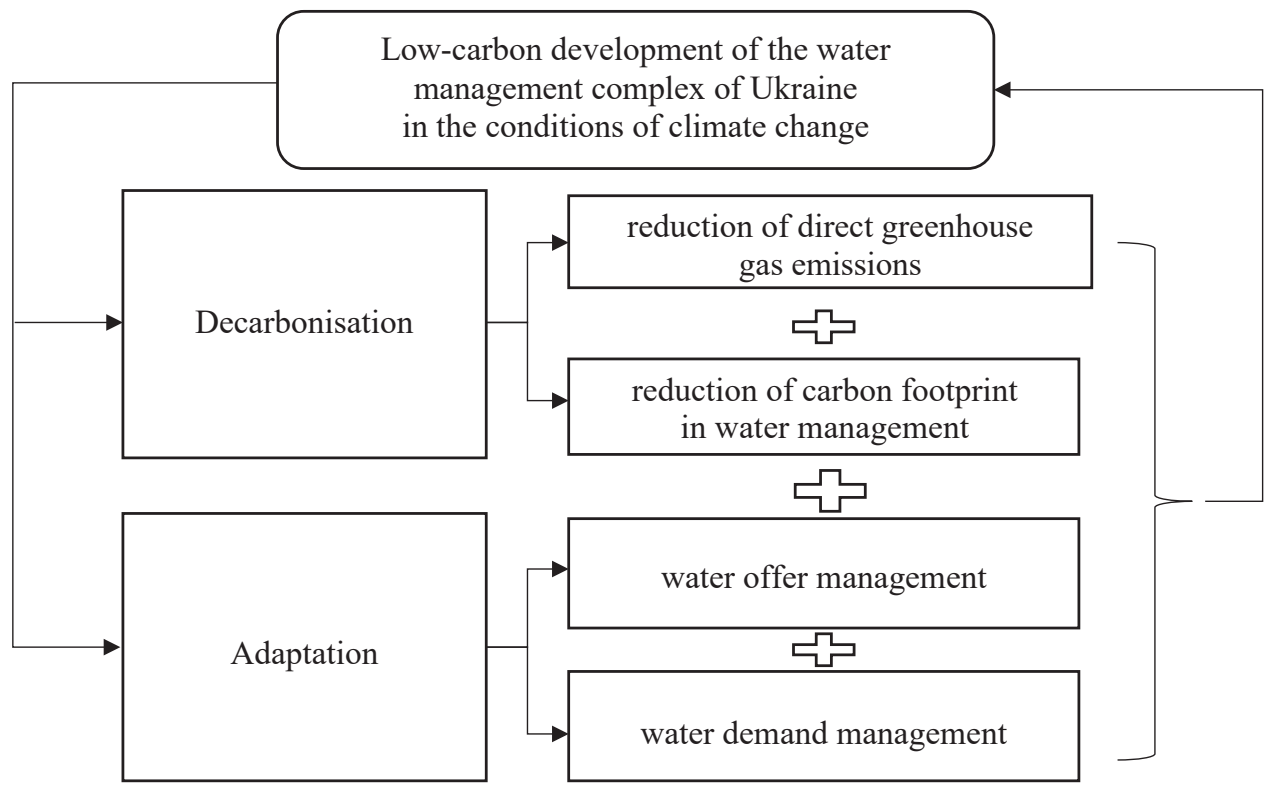

Figure 2. Directions of low-carbon development of the water management complex of Ukraine 


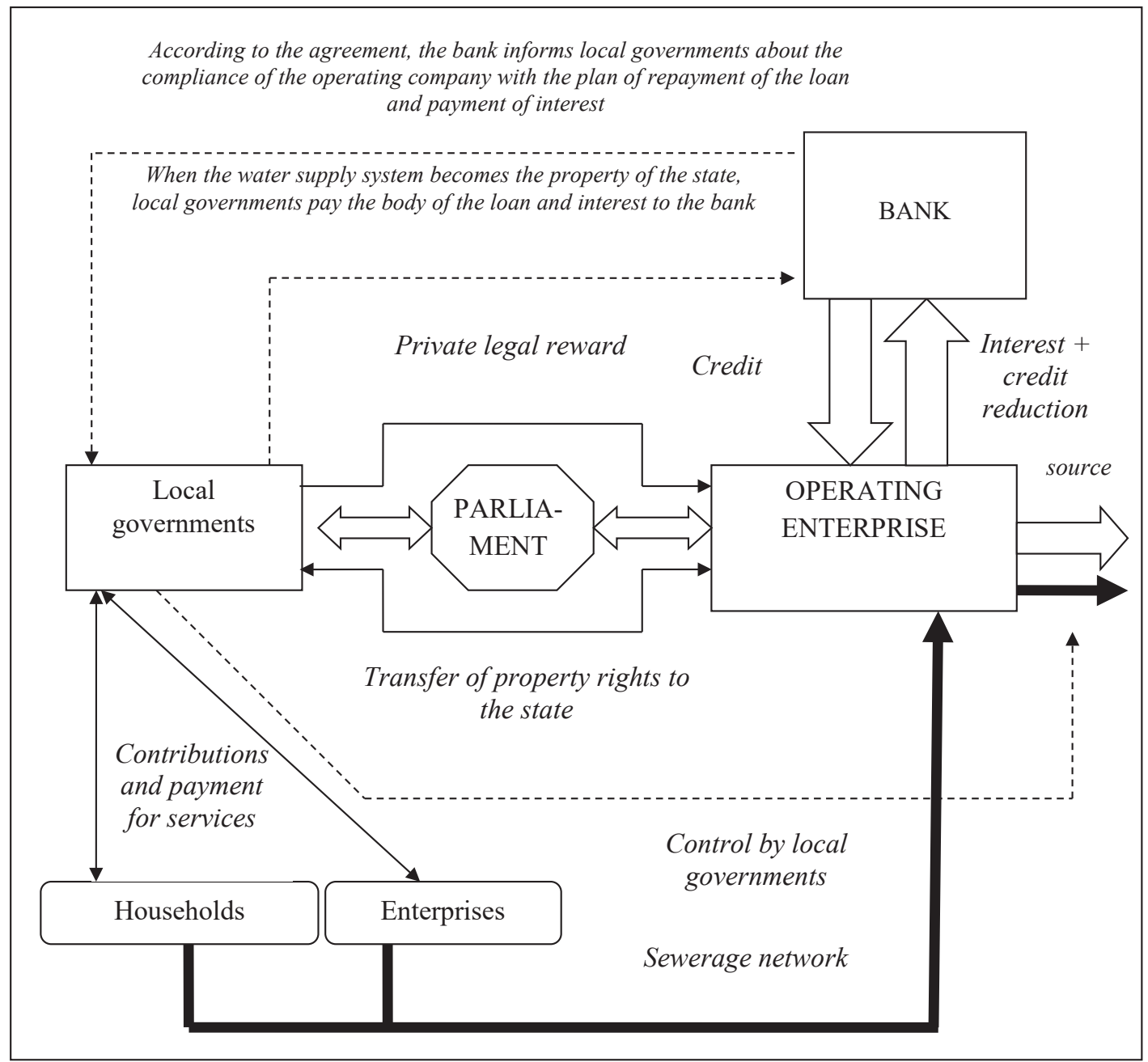

Figure 3. Model of implementation of public-private partnership in the project of the Königsbrück treatment plant (Germany)

and application of appropriate methods of adaptation of water supply systems in the context of implementing the concept of low-carbon development of the water complex of Ukraine. These methods can be conditionally structured on two approaches: infrastructural or water supply management and institutional or water demand management. However, the implementation of measures to decarbonise the water management complex of Ukraine imposes additional requirements on the priority of the application of certain adaptation methods. For example, most extensive methods of managing the demand for water resources allow to attract a significant amount of water resources relatively quickly to achieve sustainable development goals, but their use also causes additional greenhouse gas emissions and causes irreversible changes in natural ecosystems.

A characteristic trend of recent decades is the combination of the advantages of infrastructural and ecosystem approaches to water management, which has given impetus to the development of a system of methods for regulating water supply based on the construction of green infrastructure, which in the context of the implementation of the concept of lowcarbon development of the water management complex of Ukraine should be a priority.

Green water management infrastructure, in general, is a set of natural or restored natural ecosystems that complement, increase or improve the level of water supply services of traditional water infrastructure. The most typical examples of green water infrastructure are wetlands, forest protection zones, permeable pavement, restored river floodplains, etc.

The development of the green infrastructure network for sustainable water supply has a number of advantages over traditional methods of overcoming the water deficit problem. In addition to meeting the growing needs of the population and the economy in water resources, the construction of relevant facilities significantly improves the overall condition of aquatic ecosystems, which, in turn, increase the 
flow of relevant services and benefits. In particular, the ecological capacity and resilience of the territory is increased, which is extremely important in conditions of unpredictable climate change, the biodiversity of natural ecosystems is maintained, manifestations of dangerous geomorphological phenomena such as soil erosion, karst processes, shoreline erosion, etc. are prevented (Stehnei, 2018 and Vyshnevska, 2019).

All of the above areas of low-carbon development need to be integrated into one water policy system, which should be implemented at the international, national, regional and local levels. In our view, such a water policy should be based on three key principles: integrated use of existing and promising approaches to low-carbon water management, integrated water resources management, awareness of their crucial ecosystem value and role.

\section{Conclusion}

As a result of the study, the relationship between climate change and freshwater resources was analyzed, which is of particular interest in the context of achieving the goals of sustainable development. It is proved that the dynamics of increasing the number of dangerous hydrometeorological phenomena and the growth of overall water risk due to global warming require appropriate adaptation measures for all sectors of water consumption in the framework of the lowcarbon development strategy. It is substantiated that the main principle of implementation of the concept of sustainable low-carbon development of the water sector is the introduction and harmonization of such measures, which on the one hand, should minimize the negative effects of climate change on water resources and help reduce the carbon footprint from water management activities, and, on the other hand, to ensure the achievement of the goals of sustainable development, in particular with regard to the guaranteed provision of society with clean water and proper sanitary conditions. In this context, the process of decarbonisation of the water sector should be aimed at creating conditions and implementing measures for its low-carbon development and provides for the reduction and, in the long run, preventing greenhouse gas emissions from water management activities in order to mitigate climate change and preserve aquatic ecosystems.

Based on the assessment of water management, priority mechanisms and measures for their decarbonisation are proposed. In particular, such measures in the water treatment sector, which is the main emitter of methane in the water complex of Ukraine include technical re-equipment of water treatment facilities, the introduction of regenerated water use systems, creation of closed industrial water supply systems through public-private partnership mechanisms. The priority decarbonisation measures of other sectors of the water management complex of Ukraine include modernization of water supply networks and pumping equipment, the introduction of drip irrigation systems and reversible water use, the formation of integrated water resources management systems.

It has been proven that the development of a network of green infrastructure for sustainable water supply has several advantages over traditional methods of water resources management in the context of implementing a strategy of low-carbon development and adaptation to climate change. The construction of relevant facilities significantly improves the overall condition of aquatic ecosystems, which, in turn, increase the flow of their services and benefits. In particular, the ecological capacity and stability of the territory are increased, the manifestations of dangerous hydrometeorological phenomena are prevented, which is extremely important in the conditions of unpredictable climate changes. In order to implement the priority measures of adaptation and decarbonisation of the water management complex of Ukraine, it is necessary to coordinate the existing and future plans of integrated river basin management with the key principles of the concept of low-carbon development.

\section{References:}

Pachauri, R., \& Meyer, L. (2014). Climate Change 2014: Synthesis Report. Geneva, Switzerland.

Hu Yuan, Peng Zhou, \& Dequn Zhou (2011). What is Low-Carbon Development? A Conceptual Analysis. Energy Procedia, vol. 5, pp. 1706-1712.

Irtyshcheva, I., Ponomarova, M., \& Dolzhykova, I. (2019). Conceptual fundamentals of development of the food security system. Baltic Journal of Economic Studies, vol. 5, no. 2, pp. 57-64. doi: 10.30525/2256-0742/20195-2-57-64

Haidutskyi, I. P. (2014). Transnatsionalna paradyhma staloho nyz'kovuhletsevoho rozvytku [Transnational paradigm of sustainable low carbon development]. Ekonomika ta derzhava, vol. 5, pp. 14-19. Available at: http:/9www.economy.in.ua/pdf/5_2014/5.pdf

International Standard Organisation (2006). Environmental management - life cycle assessment: Requirements and Guidelines. ISO 14044.

Fritsche U.R. Comparison of Greenhouse-Gas Emissions and Abatement Cost of Nucleat and Alternative Energy Options form a Life-Cycle Perspective. Darmstadt. Oko-Institute, 1997:11 p. Available at: http://www.rachel.org/ lib/nuke_ghg_emissions.060224.pdf(accessed 09 September 2020). 
Ukrainian Hydrometeorological Institute National Academy of Sciences of Ukraine (2020). Final report on the results of the R\&D "Spatial analysis of changes in the water regime of surface water bodies in Ukraine due to climate change". Available at: http://uhmi.org.ua/project/rvndr/avr.pdf (accessed 09 September 2020).

Griffiths-Sattenspiel, B., \& Wendy, W. (2009). The Carbon Footprint of Water. Portland. Wilson Published, Available at: https://www.rivernetwork.org/wp-content/uploads/2015/10/The-Carbon-Footprint-of-WaterRiver-Network-2009.pdf

Stehnei, M., Irtyshcheva, I., \& Gurina, O. (2018). Financial mechanism of the socio-oriented economic development of the Black Sea region. Baltic Journal of Economic Studies, vol. 4, no. 4, pp. 202-208. doi: $10.30525 / 2256-0742 / 2018-4-4-202-208$

UNEP. Green Infrastructure Guide for Water Management: Ecosystem-based management approaches for waterrelated infrastructure projects. United Nations Environment Programme publication, 2014:76 p. Available at: http://www.unepdhi.org/-/media/microsite_unepdhi/publications/documents/unep/web-unep-dhigroupgreen-infrastructure-guide-en-20140814.pdf (accessed 09 September 2020).

Vyshnevska, O., Kaliuzhna, O., \& Irtyshcheva, I. (2019). Infrastructure provision of the agrarian market in the globalized environment. Baltic Journal of Economic Studies, vol. 5, no. 5, pp. 39-46. doi: 10.30525/2256-0742/20195-5-39-46 